\section{Impact Of Lateral Separations Between Pit Latrines And Wells On Contamination of Groundwater In The Tano Districts Of Ghana}

\section{F. Awuah, MSc}

Department of Science, Abetifi Presbyterian College of Education, Abetifi Kwahu, Ghana. Department of Theoretical and Applied Biology, Kwame Nkrumah University of Science and Technology, Kumasi, Ghana

\section{R.C. Abaido, PhD}

\section{K. Badu, PhD}

Department of Theoretical and Applied Biology, Kwame Nkrumah University of Science and Technology, Kumasi, Ghana

\section{S. Appah, PhD}

Department of Science, Abetifi Presbyterian College of Education, Abetifi Kwahu, Ghana

Submitted: 16 June 2020

Accepted: 28 August 2020

Published: 30 November 2020

Corresponding author:

Frank Awuah

\section{DOI: $\underline{10.19044 / \text { esj.2020.v16n33p303 }}$}

(c) Copyright 2020 Awuah et al. Distributed under Creative Commons BY-NC-ND 4.0 OPEN ACCES

Cite as:

Awuah F, R.C. Abaido, K. Badu, S. Appah (2020). Impact Of Lateral Separations Between Pit Latrines And Wells On Contamination Of Groundwater In The Tano Districts Of Ghana European Scientific Journal, ESJ, $16 \quad$ (33), 303. https://doi.org/10.19044/es].2020.v16n33p303

\begin{abstract}
:
The people in the Tano Districts of Ghana use groundwater as a source of drinking water and pit latrines for sanitation. However, when pit latrines and wells coexist, it is of paramount importance to ensure safer distances between them. This is to avoid faecal contamination of the groundwater. This study sought to investigate the impact of lateral separations between pit latrines and the wells on groundwater contamination in the Tano Districts of Ghana. To obtain a sample size of 15 wells within the proximity of pit latrines, a simple random sampling was considered in this study. It was revealed that none of the sites satisfied the Ministry of Water Resources, Works and Housing (MWRWH) of Ghana's (2010) 50m guideline for lateral separation between a well and a pit latrine. It was also brought to light that there was not much variation of the lateral distances with the total and faecal coliform counts in the water. Even so, the enterococci counts seemed to have an inverse variation with the lateral separations between the pit latrines and the wells in this study area. The enterococci might be a better human faecal indicator than the other coliforms considered in this study. The study recommends strict enforcement of the MWRWH (2010) 50m guideline for lateral separation between a well and a pit latrine in the area studied. To investigate the human faeces as a contaminant, preference must be given to the enterococci as a faecal indicator than the other faecal determinants in this study.
\end{abstract}

Subject: Environmental Microbiology 
European Scientific Journal, ESJ

November 2020 edition Vol.16, No.33
ISSN: 1857-7881 (Print) e - ISSN 1857-7431

Keywords: Lateral Separation, Horizontal Distance, Pit Latrine, Groundwater, Contamination 


\section{Introduction:}

Awuah (2012) indicated the need for an investigation into groundwater, as there has been a paradigm shift from the perception that groundwater was devoid of any form of contamination. From the perspective of Ferrer et al. (2020), this is to reduce the diseases caused by waterborne faecal exposure. Ndoziya et al. (2019) and Naser et al. (2019) are of the view that pit latrines have the potential to put groundwater at the risk of contamination, thereby threatening human health. In the view of DíazAlcaideand Martínez-Santos (2019), this becomes a threat to human lives when the pit latrines coexist with wells used for domestic purposes. In research investigating the risk of pit latrine to the groundwater, (Rao et al., 2020; Pujari et al., 2012; Graham and Polizzotto, 2013; Nyenje et al., 2013; Rao et al., 2013) surd pit latrines have the potential to cause groundwater nitrate pollution. In the words of Houéménou et al. (2020), pit latrines among others can degrade shallow aquifer, meaning that faecal contaminants can migrate to the groundwater resources. Ngasala (2019) noticed that Pit latrines can have significant contamination effect on groundwater resources. Therefore, the enforcement of a new regulatory distance between groundwater resources and sanitation systems was suggested

To reduce the above risky effect of pit latrine groundwater contamination, the distance between the pit latrines and groundwater resources must be taken into consideration. Abdulkadir et al. (2015) attest that in a situation of coexistence of pit latrines and wells, the wells and the pit latrines should be sited far away from one another. The meaning of far distance is not clearly spelt out in this study. That is, what distance between a pit latrine and a well can be described as far away? To be specific, WHO (2010) indicates that, wells should be located at least $30 \mathrm{~m}$ away from pit latrines to make them safe drinking water resources. However, Kimani-Murage and Ngidu (2007) in a study to deduce the effect of lateral separations between pit latrines and wells on groundwater contamination, proposed a lateral separation guideline of $15 \mathrm{~m}$, below which pit latrines could have a significant effect on the groundwater resources.

The difference in the guideline limits is due to the difference in the environment where each study was conducted. The horizontal distance between a pit latrine and a well in one District in Ghana having a significant effect on the groundwater, might not have a significant effect on the groundwater resource in another District of this same country.

Although Pit latrines are projected as a safe method of excreta disposal, their potential impact on groundwater contamination is neglected (Nawab et al., (2017). The Tano Districts are of no exception of this negligence, even though the people in this Districts use groundwater as the source of drinking water and for other domestic purposes while employing pit latrine for sanitation, with many people in this area reporting of gastroenteritis (Awuah, 2012). 
To investigate the effect of pit latrines on groundwater contamination, faecal indicator bacteria present in the wells coexisting with pit latrines can be of greater help. Ferrer et al. (2020) realized that, the concentration of pit latrines in an area of wells could influence the presence of Esherichia coli in the water contained in the wells. The presence of $E$. coli makes the water unsafe for drinking. Any pathogenic microorganism or any bacteria indicative of faecal pollution should not be present in drinking water (WHO, 2011). This is because when coliform bacteria are present in water, they are indicative of human faecal contamination (Petrisor, 2012; Boehm and Sassoubre, 2014). In this paper, the total coliforms, faecal coliforms and the enterococci will be employed to determine the effect of pit latrines' lateral separations between the wells in the Tano Districts on the faecal contamination of these groundwater resources in this study area.

Therefore, this paper seeks to research into the impact of lateral separations between pit latrines and wells on the groundwater in the Tano Districts.

\section{Methodology}

\section{The Area under Study}

District profile (2010) in Awuah (2012) reveals that the study area comprises the Tano Districts, Tano North and Tano South. Duayaw Nkwanta and Techire are in the Tano North District. Meanwhile, Tehimantia is within the Tano South District. This area under consideration falls within the granite metasedimentary belt, with soil made up of mainly clayey and therefore has the greater capacity to retain water for plant use. Tano North and Tano South Districts understudy area are in the semi-equatorial climatic zone with double maximum rainfall. While the major rainfall season is from March to July, the minor season is between September and November. This area has a mean annual rainfall of about $1250 \mathrm{~mm}$ with a mean temperature of relatively 26-30 degrees Celsius and humidity of 75 - 80\%. The temperature conditions in this area are conducive for the cultivation of tropical crops such as cocoa, plantain, cassava, palm oil and maize. The people in these Districts rely mainly on handdug wells, boreholes and pipe-borne water for domestic purposes. Tano North and Tano South fall within the high topographical areas of the country with elevation in most parts above $270 \mathrm{~m}$. The landscape is generally of an average height of about $380 \mathrm{~m}$ with the highest elevation ranging between $360 \mathrm{~m}$ to 760 $\mathrm{m}$ above sea level.

Tano North planning unit's report from the 2010 census, indicates that Duayaw Nkwanta has a population of 16,541 and that of Techire is 4,608. From the 2010 population census, the population of Techimantia is 10,800. The Geographic Positioning System (GPS) of each sampling site was determined and was used to generate the contour map shown below. 


\section{Generated Contour Map showing the sampling sites}

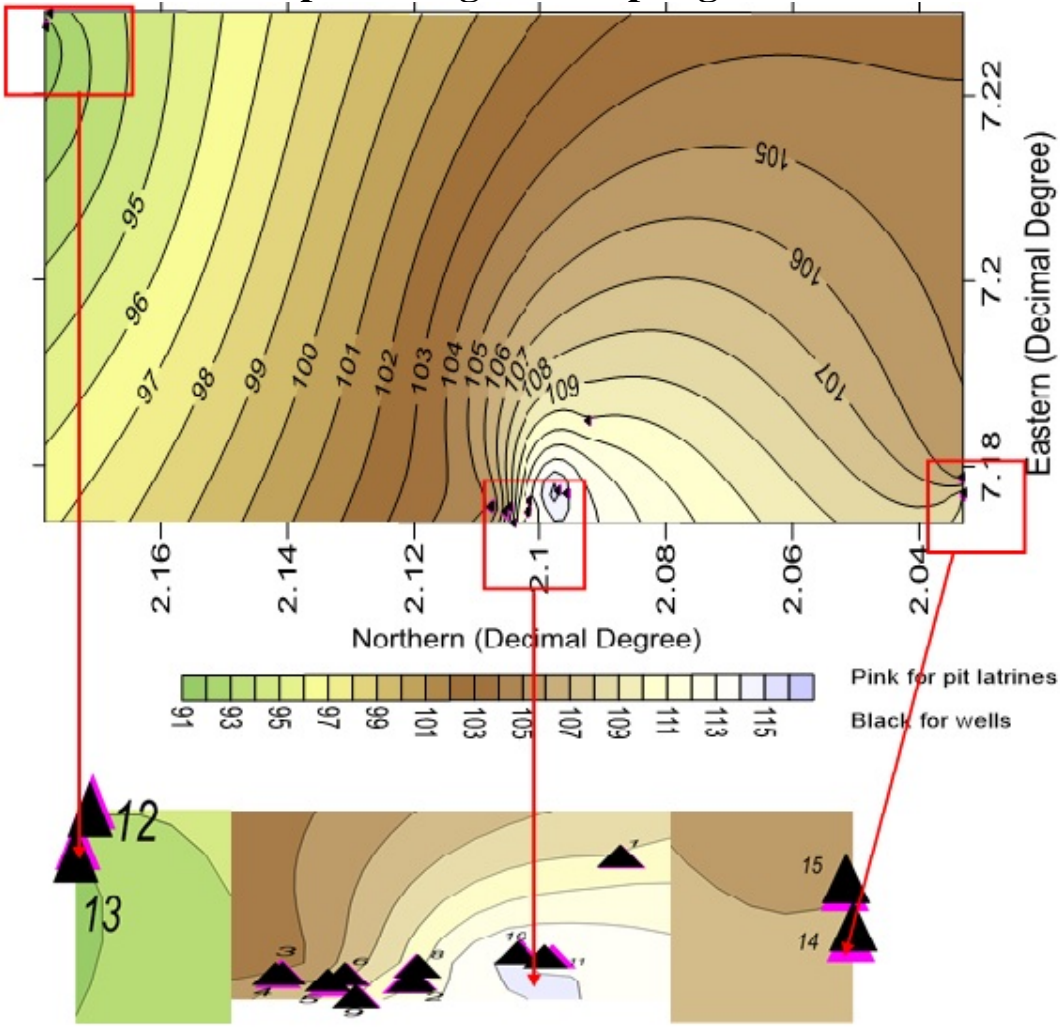

Fig 1: Area contour map with pits latrines and wells

\section{Collection of Data}

In all, fifteen (15) wells were selected randomly for the study. A 2 litre hard plastic and screw-capped bottles that have been sterilized were used to collect the water samples. A Sample was taken monthly from each well for a period of four months. In all, four samples were taken from each well. Within 2 hours of collection in a cool box containing ice packs, the samples were sent to the Science Laboratory of Department of Theoretical and Applied Biology of the Faculty of Bioscience, Kwame Nkrumah University of Science and Technology to be analysed.

\section{Procedure for Sampling}

Simple random sampling method was employed to obtain the sample size of 15 out of the total number of wells in this study area. 01 to 160 representing the total number of wells in the study area were written on pieces of paper, placed in a box and vigorously shaken. One piece of paper was selected at a time and the number on it recorded as a site where well water was to be sampled. In order to avoid biases, the selected piece of paper in each case was put back into the box to ensure that in each time of picking, there were 
160 pieces of paper in the box. This was done repeatedly until fifteen wells within the proximity of pit latrines were selected to represent the study area.

\section{Laboratory Procedures \\ Faecal Enterococci}

Serial dilutions of $10^{-1}$ to $10^{-11}$ were done by picking $1 \mathrm{ml}$ of the sample into $9 \mathrm{ml}$ sterile distilled water. A $1 \mathrm{ml}$ aliquot from each of the dilution was inoculated on a Slanetz and Barltey Agar prepared on sterile Petri dishes and incubated at a temperature of $37^{\circ} \mathrm{C}$ for 4 hours to aid bacteria resuscitation. Incubation of the plates was done at a temperature of $44^{\circ} \mathrm{C}$ for a further 44 hours. All red, maroon and pink colonies that were smooth and convex were counted and recorded as faecal enterococci after the incubation.

\section{Faecal and Total Coliforms}

Determination of the total and faecal coliforms in the samples was done using the Most Probable Number (MPN) method. In the Serial dilutions, $10^{-1}$ and $10^{-11}$ were prepared by picking $1 \mathrm{ml}$ of the sample into $9 \mathrm{ml}$ sterile distilled water. From each dilution, one millilitre aliquot was inoculated into $5 \mathrm{ml}$ of MacConkey Broth (1:5) with inverted Durham tubes and incubated at $35^{\circ} \mathrm{C}$ for total coliforms and $45^{\circ} \mathrm{C}$ for faecal coliforms for $18-24$ hours. Tubes with colour change from purple to yellow and gas collected in the Durham tubes after 24 hours were identified as positive for both total and faecal coliforms. Counts per $100 \mathrm{ml}$ were calculated from the appropriate Most Probable Number (MPN) tables.

\section{Results and Discussion}

\section{Lateral Separation and Microbial Counts}

None of the sites satisfies the Ministry of Water Resources, Works and Housing (MWRWH) of Ghana's (2010) guideline for lateral separation between a well and a pit latrine which is $50 \mathrm{~m}$ (Table 1 ).

Table 1: Lateral Separation and the mean Microbial Counts $(n=60)$

Location of Wells

$\log _{10}$ Geo mean counts/100ml and Latrines

\begin{tabular}{cccccc}
\hline Srl. & & LS/m & TC & FC & EC \\
1 & C 62/4 & 6.0 & 2.62 & 1.62 & 1.90 \\
2 & D 77/3 & 18.4 & 2.62 & 1.36 & 1.60 \\
3 & D 382/3 & 19.2 & 2.37 & 1.62 & 1.95 \\
4 & D 369/3 & 20.0 & 2.96 & 1.62 & 2.18 \\
5 & D 156/3 & 15.8 & 2.62 & 1.62 & 2.15 \\
6 & D 306/3 & 11.6 & 3.46 & 2.62 & 2.41 \\
7 & $78 / 3$ & 7.0 & 2.62 & 1.62 & 1.78 \\
8 & C 31/3 & 19.8 & 2.37 & 1.96 & 1.85 \\
\hline
\end{tabular}




\begin{tabular}{cccccc}
9 & D45/3 & 14.0 & 3.38 & 1.96 & 2.15 \\
10 & Nurses Qters A & 22.9 & 1.46 & 1.36 & 1.16 \\
11 & Nurses Qters B & 39.9 & 1.36 & 1.36 & 1.10 \\
12 & Susuanmu (A) & 36.0 & 2.62 & 0.00 & 0.00 \\
& & & & & \\
13 & Susuanmu (B) & 10.0 & 4.37 & 2.96 & 2.59 \\
14 & Saviour missionA & 24.0 & 2.96 & 1.96 & 1.88 \\
15 & Saviour mission B & 44.7 & 3.96 & 2.37 & 1.93 \\
\hline
\end{tabular}

Town $1-11$ is Duayaw Nkwanta, $12-13$ is Techire, $14-15$ is Techimamntia.LS $=$ lateral separation, $\mathrm{TC}=$ total coliform, $\mathrm{FC}=$ faecal coliform, $\mathrm{EC}=$ enterococci.

Water samples taken from the various sample sites display varying levels of bacterial counts (Table 1). The presence of these organisms in the wells has the potential to subject the people living in this vicinity to a lot of gastroenteritis. This is supported by (Loyola et al., 2020; Maramraj et al., 2020; Fakhr et al., 2016) that faecal contamination of drinking water is a frequent problem which accounts for many cases of diarrhoea. This may explain the reports gathered from the Tano North District Health Directorate (2011) in Awuah (2012) indicating that many people in the Districts complain of typhoid and other diarrhoea related diseases.

\section{Microbial Counts and Lateral Separation}

Table 2: Comparison of means of microbial counts in relation to lateral distance

\begin{tabular}{|c|c|c|c|c|}
\hline \multirow[t]{2}{*}{$\mathrm{LS} / \mathrm{m}$} & \multirow[t]{2}{*}{ Frequency } & \multicolumn{3}{|c|}{$\log _{10}$ Geo mean counts/100ml } \\
\hline & & TC & FC & EC \\
\hline $\begin{array}{l}1- \\
10\end{array}$ & 3 & $3.20(1.01)$ & $2.07(0.77)$ & $2.06(0.47)$ \\
\hline $\begin{array}{c}11- \\
20\end{array}$ & 7 & $2.87(0.41)$ & $1.82(0.41)$ & $2.04(0.26)$ \\
\hline$>20$ & 5 & $2.47(1.08)$ & $1.41(0.90)$ & $1.21(0.78)$ \\
\hline \multicolumn{5}{|l|}{ Pr } \\
\hline & $\begin{array}{c}\text { Not } \\
\text { applicable }\end{array}$ & 0.454 & 0.394 & 0.042 \\
\hline
\end{tabular}

The results obtained in Table2 show that lateral distances between pit latrines and water sources (borehole/well) do not have much influence on the total and faecal coliform counts of the water $(p>0.05)$. It is seen that the 
average total coliform counts of $\log 3.20,2.87$ and 2.47 were recorded for lateral distances between 1-10, 11-20 and $>20$ meters respectively. These differences were not statistically significant $(\mathrm{p}>0.05)$. A similar trend was observed for faecal coliforms with average counts of log 2.07, 1.82 and 1.41 for lateral distance ranges of 1-10, 11-20 and $>20$ meters respectively. The differences between the counts were not statistically significant $(\mathrm{P}>0.05)$. There might be other sources of the total and the faecal coliforms such as open defecation, poultry droppings other than the pit latrines contaminating the groundwater resources.

For enterococci, the average counts recorded for the ranges of lateral distances, 1-10, 11-20 and > 20 meters were $\log 2.06,2.04$ and 1.21 respectively. Statistically, the differences between the enterococci counts were significant $(\mathrm{P}<0.05)$. The enterococci might be a better human faecal indicator than the other coliforms considered in this study. The Total and faecal coliforms can readily be isolated in tropical waters from areas far removed from human activity and thusare not adequate indicators of faecal contamination and human health risks. Enterococci enable a better assessment of faecal contamination and public health risks. Enterococci are found in high concentrations in human faeces. Fattal et al. (1987), to determine the organism that can indicate faecal contamination stated that, of the indicators (faecal coliform, enterococci and Escherichia coli), enterococci were the most predictive indicator for enteric disease symptoms. In the Words of Kay et al. (1994), comparing the faecal indicators (total coliform, faecal coliform and enterococci), enterococci are the best indicators of gastrointestinal symptoms. The enterococci might, therefore, be better faecal determinant than the total and faecal coliforms.

In a study to compare enterococci, E. coli and faecal coliform as faecal indicators, Jin et al. (2004) indicated that enterococci might be a more stable indicator than E.coli and faecal coliform.

In general, it was observed that water samples which were close to the pit latrines had higher bacterial counts than those that are distant from them (Tables 2).

Water from Susuanmu (B) has the highest total coliforms compared to the other suburbs. The lateral distance separating the pit latrine and the well is 10 $\mathrm{m}$. The lowest total coliform count was recorded in the suburb of Nurses. The lateral distance between pit latrine and the water source in this suburb is 39.9 m.

Sudgen (2006) found that the greater the horizontal distance the pathogen had to travel from point of entry into the water table to the water point, the longer it is retained and the higherthe probability that the pathogen will die. In short, he stated that the greater the distance between the latrine and the water point, the lower the risk of contamination. Again, Sudgen (2006) 
explains that, if the time taken for a pathogen to be transferred to the water point is large, the pathogen would have died off and that, the water would no longer be a threat to public health.

Kimani-Murage and Ngidu (2007), highlighted in an explanation of the impact of the proximity of a pit latrine to a well that, where the distance between well and pit latrine is not adequate, micro-organisms can migrate from the latrine to the water.

\section{Conclusion:}

It can be concluded from this research that pit latrine groundwater contamination increases with decreasing lateral separation between the pit latrines and the wells and decreases with increasing the horizontal distance between the wells and the pit latrines in the study area. It was also revealed from this study that there might be other sources of groundwater contamination apart from the wells in this area studied. Enterococciseemed to be a better human faecal indicator than total and faecal coliforms.

It is therefore recommended to the Tano District Assemblies t, there must be strict enforcement of the MWRWH (2010) 50m guideline for lateral separation between a well and a pit latrine in the area studiedFuture researchis to be conducted to find the other sources of groundwater faecal contaminationapart from the pit latrines in the Tano Districts. Also in an attempt to determine faecal contamination, precedence must be given to enterococci as a human faecal indicator than the other coliforms.

\section{Acknowledgement}

Glory be unto the Almighty God for great thing He has done by bringing us to this far in this paper. We wish to also express our profound gratitude to a brother and Colleague, Dr Samuel Appah for being there for us anytime we called on him for assistance. We wish to appreciate Mrs Joyce Awuah and the whole of Awuah's family for their unwavering support throughout the time for this study.

\section{References:}

1. Abdukadir, R. S., Mahmoud, A. M., Adnan, A., Shamsuddeen, U., Adamu, R. T., \& Yunusa, I. (2015). Effect of pit latrine leaks on shallow well water. Int. J. Microb. Appl, 1(5), 46-51

2. Archives: District Health Directorate (2007,2008,2009,2010,2011), Diarrhoea related diseases, Tano North District, Brong Ahafo Region, Ghana

3. Austin, J. H. (1998). Zen and the brain: Toward an understanding of meditation and consciousness. Cambridge, MA: MIT Press. 
4. Awuah, F. (2012). Impact of Pit Latrines on Groundwater in Some Selected Towns in the Tano Districts (Master's dissertation).

5. Bartram, J., Cotruvo J., Exner M., Fricker, C., and Glasmacher, A. (2003), Heterotrophic Plate Counts and Drinking-Water Safety, the Significance of HPCs for Water Quality and Human Health. IWA Publishing, London.

6. Boehm, A. B., \& Sassoubre, L. M. (2014). Enterococci as indicators of environmental fecal contamination. In Enterococci: From Commensals to Leading Causes of Drug Resistant Infection [Internet]. Massachusetts Eye and Ear Infirmary.

7. Calarco, M., \& Atterton, P. (2009). Animal philosophy: Essential readings in continental thought. New York, NY: Continuum.

8. Chen, J. Q. (2003). Intelligence: Multiple intelligences. In J. Guthrie (Ed.),Encyclopedia of education (pp. 1198-1201). New York, NY: Macmillan.

9. Clancy, T., Stiner, C., \& Koltz, T. (2002). Shadow warriors: Inside the special forces. New York, NY: Putnam

10. Díaz-Alcaide, S., \& Martínez-Santos, P. (2019). Mapping fecal pollution in rural groundwater supplies by means of artificial intelligence classifiers. Journal of Hydrology, 577, 124006.

11. Fakhr, A. E., Gohar, M. K., \& Atta, A. H. (2016). Impact of some ecological factors on fecal contamination of drinking water by diarrheagenic antibiotic-resistant Escherichia coli in Zagazig City, Egypt. International journal of microbiology, 2016.

12. Fattal, B., E. Peleg-Olevsky, T. Agursky, and H.I. Shuval. 1987. The association between seawater pollution as measured by bacterial indicators and morbidity among bathers at Mediterranean bathing beaches of Israel. Chemosphere 16:565-570.

13. Ferrer, N., Folch, A., Masó, G., Sanchez, S., \& Sanchez-Vila, X. (2020). What are the main factors influencing the presence of faecal bacteria pollution in groundwater systems in developing countries?. Journal of contaminant hydrology, 228, 103556.

14. Graham, J. P., \& Polizzotto, M. L. (2013). Pit latrines and their impacts on groundwater quality: a systematic review. Environmental health perspectives, 121(5), 521-530.

15. Houéménou, H., Tweed, S., Dobigny, G., Mama, D., Alassane, A., Silmer, R., ... \& Socohou, A. (2020). Degradation of groundwater quality in expanding cities in West Africa. A case study of the unregulated shallow aquifer in Cotonou. Journal of Hydrology, 582, 124438.

16. Jin, G., Englande, A. J., Bradford, H., \& Jeng, H. W. (2004). Comparison of E. coli, enterococci, and fecal coliform as indicators for 
brackish water quality assessment. Water environment research, 76(3), 245-255.

17. Kay, D., J.M. Fleisher, R.L. Salmon, F. Jones, M.D. Wyer, A.F. Godfree, Z. Zelenauch-Jacqotte, and R. Shore. 1994. Predicting likelihood of gastroenteritis from sea bathing: Results from randomised exposure. The Lancet 344(October 1):905-909.

18. Kimani-Murage, E. W., \& Ngindu, A. M. (2007). Quality of water the slum dwellers use: the case of a Kenyan slum. Journal of Urban Health, 84(6), 829-838.

19. Loyola, S., Sanchez, J. F., Maguiña, E., Canal, E., Castillo, R., Bernal, M., ... \& Lescano, A. G. (2020). Fecal Contamination of Drinking Water Was Associated with Diarrheal Pathogen Carriage among Children Younger than 5 Years in Three Peruvian Rural Communities. The American Journal of Tropical Medicine and Hygiene, tpmd190337.

20. Maramraj, K. K., Subbalakshmi, G., Ali, M. S., Dikid, T., Yadav, R., Sodha, S. V., ... \& Singh, S. K. (2020). A community-wide acute diarrheal disease outbreak associated with drinking contaminated water from shallow bore-wells in a tribal village, India, 2017. BMC Public Health, 20(1), 1-8.

21. MWRWH(2010), Small Towns Sector Guidelines. Ghana Community Water and Sanitation Agency.PP 7.

22. Naser, A. M., Doza, S., Rahman, M., Ahmed, K. M., Gazi, M. S., Alam, G. R., ... \& Ercumen, A. (2019). Sand Barriers around Latrine Pits Reduce Fecal Bacterial Leaching into Shallow Groundwater: A Randomized Controlled Trial in Coastal Bangladesh. Environmental science \& technology, 53(4), 2105-2113.

23. Nawab, B., Esser, K. B., \& Baig, S. A. (2017). Impact of pit latrines on drinking water contaminations in Khyber Pakhtunkhwa, Pakistan. Environmental Forensics, 18(4), 296-306.

24. Ndoziya, A. T., Hoko, Z., \& Gumindoga, W. (2019). Assessment of the impact of pit latrines on groundwater contamination in Hopley Settlement, Harare, Zimbabwe. Journal of Water, Sanitation and Hygiene for Development, 9(3), 464-476.

25. Ngasala, T. M., Masten, S. J., \& Phanikumar, M. S. (2019). Impact of domestic wells and hydrogeologic setting on water quality in periurban Dar es Salaam, Tanzania. Science of the total environment, 686, 1238-1250.

26. Nyenje, P. M., Foppen, J. W., Kulabako, R., Muwanga, A., \& Uhlenbrook, S. (2013). Nutrient pollution in shallow aquifers underlying pit latrines and domestic solid waste dumps in urban slums. Journal of environmental management, 122, 15-24. 
27. Petrisor, I. G. (2012). Emerging Environmental Forensics Applications and Case Studies: Review of Environmental Forensics-Proceedings of the 2011 INEF Conference.

28. Pujari, P. R., Padmakar, C., Labhasetwar, P. K., Mahore, P., \& Ganguly, A. K. (2012). Assessment of the impact of on-site sanitation systems on groundwater pollution in two diverse geological settingsa case study from India. Environmental monitoring and assessment, 184(1), 251-263.

29. Rao, S. M., Mogili, N. V., \& Arkenadan, L. (2020). Role of evaporation in NH4-N transformations in soils artificially contaminated with blackwater. Water Supply, 20(1), 165-172.

30. Rao, S. M., Sekhar, M., \& Rao, P. R. (2013). Impact of pit-toilet leachate on groundwater chemistry and role of vadose zone in removal of nitrate and E. coli pollutants in Kolar District, Karnataka, India. Environmental earth sciences, 68(4), 927-938.

31. Schmoll, O., Howard, G., Chilton, J., \& Chorus, I. (Eds.). (2006). Protecting groundwater for health: managing the quality of drinkingwater sources. World Health Organization.

32. Sugden S., (2006), The Microbiological Contamination Of Water Supplies, Sandy Cairncross; Well Factsheet. Retrieved from https://www.lboro.ac.uk/research/wedc/well/water-supply/wsfactsheets/microbiological-contamination/

33. WHO (2011), Guideline for Drinking Water Quality. Recommendations, 4th. Ed. World Health Organization, Geneva; Retrieved on 02/02/2020 from www.iasaude.pt/attachments/article/660/WHO_Guidelines\%20for\%2 0drinking-water\%20quality.pdf

34. World Health Organization (2010), Guidelines for Drinking Water Quality. Revision of' the 1984 Guidelines. Final Task Group Meeting, Geneva. 